\title{
PENGARUH METODE KOOPERATIF TGT DAN NHT TERHADAP PRESTASI DAN KEPUASAN PEMBELAJARAN KELISTRIKAN OTOMOTIF DI SMK
}

\author{
Purnawan \\ SMK Ma'arif 1 Nanggulan Kulon Progo \\ urnawan04@yahoo.co.id \\ Soenarto \\ Universitas Negeri Yogyakarta \\ narto_elka@yahoo.com
}

\begin{abstract}
Abstrak
Penelitian ini bertujuan untuk: (1) mengetahui pengaruh penggunaan metode pembelajaran kooperatif tipe TGT dan pembelajaran kooperatif tipe NHT terhadap prestasi belajar dan kepuasan pembelajaran kelistrikan otomotif siswa, dan (2) membandingkan keefektifan metode pembelajaran kooperatif tipe TGT dan tipe NHT terhadap prestasi belajar dan kepuasan pembelajaran kelistrikan otomotif siswa SMK. Penelitian ini adalah quasi experiment dengan desain pretest-posttest with nonequivalent group design. Populasi penelitian ini adalah seluruh siswa kelas XI SMK Ma'arif 1 Nanggulan Kulon Progo. Sampel dipilih sebanyak dua kelas dengan menggunakan teknik simple random sampling. Kelompok eksperimen 1 diberi perlakuan TGT dan kelompok eksperimen 2 diberi perlakuan NHT. Teknik pengumpulan data yang digunakan adalah tes dan kuisioner. Tes digunakan untuk mengetahui prestasi belajar siswa sebelum dan sesudah perlakuan. Kuisioner digunakan untuk mengetahui kepuasan belajar siswa sebelum dan sesudah perlakuan. Teknik analisis data yang digunakan adalah dengan uji t. Hasil penelitian menunjukan: (1) metode pembelajaran kooperatif tipe TGT dan NHT efektif ditinjau dari prestasi belajar dan kepuasan pembelajaran siswa SMK, dan (2) metode pembelajaran kooperatif tipe TGT lebih efektif dibanding metode pembelajaran kooperatif tipe NHT terhadap prestasi belajar dan kepuasan pembelajaran kelistrikan otomotif siswa SMK.
\end{abstract}

Kata Kunci: metode pembelajaran kooperatif tipe TGT, metode pembelajaran kooperatif tipe NHT, prestasi belajar, kepuasan pembelajaran

\section{THE EFFECT OF THE COOPERATIVE METHOD OF TGT AND NHT ON THE LEARNING ACHIEVEMENT AND SATISFACTION IN AUTOMOTIVE ELECTRICITY OF THE SMK}

\begin{abstract}
This study aims to: (1) investigate the effects of the application of the cooperative learning method of the Teams Games Tournament (TGT) type and that of the Numbered Head Together (NHT) type on the students'learning achievement and satisfaction in automotive electricity, and (2) compare the effectiveness of cooperative learning methods of the TGT type and that of the NHT type of learning achievement and learning satisfaction of automotive electrical vocational students. This was a quasi-experimental study employing the pretest-posttest-with-nonequivalent-group design. The research population comprised all Grade XI students of SMK Ma'arif 1 Nanggulan, Kulon Progo. The sample, consisting of two classes, was established by means of the simple random sampling technique. Experimental Group 1 received a treatment of the cooperative learning of the TGT type and Experimental Group 2 received a treatment of the cooperative learning of the NHT type. The data were collected through tests and questionnaires. The tests were administered to assess the students' learning achievement before and after the treatment. The questionnaires were administered to investigate their learning satisfaction before and after the treatment. The data were analyzed by means of the t-test. The results of the study showed that: (1) TGT cooperative learning method and types of
\end{abstract}


NHT effective in terms of learning achievement and learning satisfaction of vocational students, and (2) TGT cooperative learning methods is more effective than NHT cooperative learning methods to learning achievement and learning satisfaction of automotive electrical vocational students.

Keywords: cooperative learning of the TGT type, cooperative learning of the NHT type, learning achievement, learning satisfaction

\section{PENDAHULUAN}

Menurut UU Sisdiknas No. 20 Tahun 2003 pasal (1) dijelaskan bahwa Pendidikan adalah usaha sadar dan terencana untuk mewujudkan suasana belajar dan proses pembelajaran agar peserta didik secara aktif mengembangkan potensi dirinya untuk memiliki kekuatan spiritual keagamaan, pengendalian diri, kepribadian, kecerdasan, akhlak mulia serta keterampilan yang diperlukan dirinya, masyarakat bangsa dan negara. Dapat dipahami bahwa potensi manusia untuk berkembang sangat tergantung pada kualitas proses pelaksanaan pembelajaran yang diperoleh, sehingga hal ini menjadi tantangan tersendiri bagi pemikir, perencana, dan pelaksana pendidikan untuk merencanakan dan mengembangkan sistem pendidikan nasional yang relevan dengan tuntutan masyarakat yang terus berkembang sesuai dengan perubahan jaman.

Sebagai bagian dari sistem pendidikan nasional, Sekolah Menengah Kejuruan (SMK) merupakan pendidikan pada jenjang menengah yang menyiapkan peserta didiknya untuk memasuki dunia kerja/industri dengan berbekal ilmu pengetahuan dan keahlian sehingga diharapkan mampu mengembangkan ilmu dan keahlian yang diperolehnya itu demi kemajuan dirinya, masyarakat dan bangsa. Tidak hanya kebutuhan dalam belajar di sekolah, tetapi kualitas lulusan SMK di dunia kerja menjadi tolok ukur keberhasilan pelaksanaan proses pendidikan kejuruan. Seperti yang diungkapkan oleh Finch (1999, p.14):

The ultimate success of a vocational and technical curriculum is not measured merely through student educational achievement but through the result of that achievement-result that take the form of permormance in the work world. Thus, the vocational and technical curriculum is oriented toward process (experience and activities within the school setting) and product (effect of these experiences and activities on former student).

Dari paparan tersebut dapat disimpulkan bahwa keberhasilan utama kurikulum kejuruan dan teknik tidak diukur hanya melalui prestasi pendidikan siswa tetapi melalui prestasi dalam bentuk kinerja lulusan di dunia kerja. Dengan demikian, kurikulum SMK berorientasi pada proses (pengalaman dan kegiatan dalam lingkungan sekolah) dan produk (efek dari pengalaman-pengalaman dan kegiatan siswa). Hal tersebut juga ditegaskan dalam penjelasan UU Sisdiknas No. 20 Tahun 2003 pasal (15) yang menyatakan bahwa SMK sebagai bentuk satuan pendidikan kejuruan merupakan pendidikan menengah yang mempersiapkan peserta didik terutama untuk bekerja dalam bidang tertentu. Hal ini menunjukkan betapa besar harapan pemerintah terhadap SMK dalam mempersiapkan tenaga kerja yang dibutuhkan dalam pembangunan. Dengan berbagai keterampilan yang diperoleh maka siswa lulusan SMK tidak hanya siap mengisi lapangan pekerjaan, tetapi lebih jauh lagi diharapkan dapat menciptakan lapangan kerja serta mampu untuk mengikuti perkembangan dan perubahan yang terjadididalam masyarakat, bangsa dan negara yang tidak terlepas dari pengaruh perubahan global, perkembangan ilmu pengetahuan dan teknologi, serta seni dan budaya.

Pendidikan Nasional Indonesia bertujuan untuk meningkatkan kualitas manusia seutuhnya, yaitu manusia yang berbudi pekerti luhur, kepribadian maju, tangguh, cerdas, kreatif, terampil, disiplin, beretos kerja profesional, bertanggung jawab, produktif, sehat jasmani dan rohani. Untuk mencapai tujuan pendidikan nasional tersebut kualitas proses pembelajaran harus diupayakan dengan pengetahuan-pengetahuan dan perbaikanperbaikan sesuai kebutuhan melalui inovasi pendidikan.

Banyak cara yang telah dilakukan agar pendidikan berhasil, salah satunya pendidikan 
sepanjang hayat. Pendidikan sepanjang hayat juga disebut pendidikan seumur hidup atau long life education. Pendidikan ini menuntut agar pendidikan tidak hanya dilakukan pada masa anak-anak atau pada masa remaja saja, melainkan pendidikan mulai dari anak-anak, remaja, dewasa, sampai masa tua, bahkan ada yang menyebut dari masa dalam kandungan ibu pendidikan sudah harus diberlakukan.

Aktivitas pendidikan dapat berlangsung dalam keluarga, dalam sekolah dan dalam masyarakat. Dalam keluarga, pendidikan orang tua yang diperlukan, mulai dari pemberian teladan kepada anak mengenai norma-norma dalam keluarga, mengenai teladan pola keluarga dan sebagainya. Di masyarakat pendidikan dapat dilakukan dengan normanorma dan aturan di masyarakat, tingkah laku di masyarakat serta adat istiadat yang berlaku di masyarakat. Sedangkan di sekolah, biasanya pendidikan yang diberlakukan adalah formal. Pendidikan formal dengan mempelajari ilmu pengetahuan sesuai dengan bidang keahlian masing-masing siswa.

Proses pembelajaran telah diatur dalam peraturan menteri pendidikan nasional no. 41 tahun 2007. Peraturan tersebut menyatakan proses pembelajaran pada satuan pendidikan diselenggarakan secara interaktif, inspiratif, menyenangkan, menantang, memotivasi peserta didik untuk berpartisipasi aktif, serta memberikan ruang yang cukup bagi prakarsa, kreatifitas, dan kemandirian sesuai dengan bakat, minat, dan perkembangan fisik serta psikologi peserta didik. Karena sekolah berperan penting dalam mengembangkan potensi anak menjadi manusia yang bermutu diperlukan layanan pendidikan yang berorientasi pada kebutuhan siswa. Untuk membutuhkan manusia yang berkualitas dibutuhkan proses pendidikan yang berkualitas pula. Untuk itu salah satu upaya pemerintah dalam meningkatkan mutu pendidikan sekolah adalah perbaikan proses belajar mengajar yang berkualitas.

Dalam kenyataannya banyak faktor yang mempengaruhi belajar. Menurut Sugihartono dkk (2007, p.76) terdapat 2 faktor yang mempengaruhi belajar, yaitu: faktor internal dan faktor eksternal.

\section{Faktor Internal}

Faktor internal adalah faktor yang ada dalam diri individu yang sedang belajar. Faktor internal ini meliputi: faktor jasmaniah dan faktor psikologis

\section{Faktor Eksternal}

Faktor eksternal adalah faktor yang ada diluar individu yang sedang belajar. Faktor eksternal ini meliputi: faktor keluarga, faktor sekolah, faktor masyarakat

Beberapa definisi tersebut diperjelas oleh Sanjaya (2007, p.52) bahwa faktor-faktor yang berkaitan dengan sistem pembelajaran adalah sebagai berikut:

\section{Faktor Guru}

Guru adalah komponen yang sangat menentukan dalam suatu pembelajaran. Tanpa adanya guru, sebagus apapun strategi yang telah di rencanakan maka tidak dapat di aplikasikan karena pelaksana suatu strategi sendiri adalah seorang guru. Guru tidak dapat di gantikan misalnya oleh sebuah media lain. Akan sangat berbeda misalnya hanya digantikan oleh media Televisi, Komputer atau hanya sebuah buku ajar. Guru adalah sebuah manager of learning dalam suatu pembelajaran di kelas.

\section{Faktor Siswa}

Siswa merupakan faktor indikator suatu keberhasilan pendidikan. Jika output siswa setelah diajar menjadi lebih baik daripada sebelumnya bisa dikatakan pembelajaran berhasil. Sikap siswa yang mempunyai karakteristik yang berbeda-beda berpengaruh terhadap proses pembelajaran. Kadang ditemukan siswa yang aktif dan kadang tidak sedikit siswa yang pasif. Ditemukan juga siswa yang dari latar belakang yang berbeda antara satu dengan yang lainnya. Semuanya itu akan mempengaruhi proses pembelajaran di kelas.

\section{Faktor Sarana dan Prasarana}

Sarana merupakan sesuatu yang
mendukung secara langsung terhadap
kelancaran proses pembelajaran. Beberapa
contoh sarana misalnya media pembelajaran,
alat-alat pelajaran, perlengkapan sekolah, dan
lain sebagainya. Sedangkan prasarana adalah


segala sesuatu yang secara tidak langsung dapat mendukung keberhasilan proses pembelajaran misalnya jalan menuju sekolah, penerangan sekolah, kamar kecil, dan lain sebagainya.

\section{Faktor Lingkungan}

Faktor pertama dari faktor lingkungan adalah organisasi kelas. Jika kelas yang terlalu besar akan lebih sulit untuk mencapai tujuan pembelajaran. Dalam kelas besar perbedaan individu akan semakin besar juga, membutuhkan waktu diskusi lebih lama, partisipatif siswa akan cenderung menurun karena ketidak mampuan guru dalam mengelola kelas.

Keberhasilan proses pendidikan di sekolah tidak hanya ditentukan oleh guru dan siswa, tetapi juga pemilihan metode pembelajaran yang tepat. Menurut Dittrich et al. (2009, p.17), dalam proses pembelajaran guru dituntut menjadi social worker, psychologist, mediator, communicator, team worker, knowledge networker, and an expert. Salah satu metode pembelajaran yang mendekati konsep ini diantaranya adalah metode pembelajaran kooperatif (cooperative learning). Metode cooperative learning menekankan pada diskusi atau kerjasama serta memungkinkan siswa untuk saling bertukar gagasan dan ide dalam kelompok, sehingga dalam prosesnya siswa akan menjadi lebih aktif. Hal tersebut sesuai dengan yang diungkapkan Slavin (1995, p.5):

All cooperative learning methods share the idea that students work together to learn and are responsible for their teammates 'learning as well as their own. These methods emphasise the use of team goals and team success which can be achieved only if all members of the team learn the objectives being taught.

Dari paparan tersebut berarti bahwa semua metode pembelajaran cooperative learning menyumbangkan ide bahwa siswa bekerja sama dan bertanggung jawab terhadap teman dalam satu timnya serta dirinya sendiri. Karena pada metode cooperative learning akan berhasil bila semua anggota team dapat bekerja sama dengan baik serta mampu membuat diri mereka belajar sama baiknya.
Cooperative learning lebih dari sekedar belajar kelompok atau kerja kelompok karena dalam pembelajaran cooperative learning terdapat struktur dorongan atau tugas yang bersifat kooperatif sehingga memungkinkan terjadinya interaksi secara terbuka dan hubungan yang efektif diantara anggota kelompok. Hal tersebut sesuai dengan yang dikemukakan Jacobs (http:// www.readingmatrix.com) mengatakan bahwa cooperative learning involves more than just asking students to work together in groups. Instead, conscious thought goes in to helping students make the experience as successful as possible. Dari paparan tersebut di simpulkan bahwa cooperative learning tidak sekedar melakukan pembelajaran secara berkelompok, tapi lebih jauh lagi untuk membuat siswa mengalami pengalaman belajar semaksimal mungkin. Hubungan efektif antar anggota kelompok terbentuk karena adanya keterkaitan dalam kelompok. Hal ini sesuai dengan yang dikemukakan oleh Wachanga dan Mwangi (2004, p.33)

Positive interdependence is critical to successful application of the Cooperative Class Experiment CCE teaching method. It benefits both the weak and bright students because group memberships and interpersonal interaction are not, in themselves, sufficient to produce higher achievement and productivity.

Dari paparan tersebut disimpulkan bahwa ketergantungan antar anggota kelompok yang bersifat positif dapat menghasilkan prestasi belajar yang lebih baik dan produktif. Dalam cooperative learning siswa berprestasi juga diangap sebagai sumber belajar yang bisa membantu siswa lainya.

Menurut Solihatun dan Raharjo (2009, p.4) Cooperative learning adalah suatu sikap dalam bekerja sama yang teratur dalam kelompok dan keberhasilan kerja dipengaruhi keterlibatan anggota kelompok. Sedangkan menurut Suprijono (2010, p.54) cooperative learning adalah konsep yang lebih luas meliputi semua jenis kerja kelompok yang diarahkan oleh guru. cooperative learning atau pembelajaran kooperatif merupakan pendekatan yang baik untuk meningkatkan keaktifan siswa. 
Cooperative Learning mengacu pada metode pengajaran dimana siswa bekerja bersama dalam kelompok kecil saling membantu dalam belajar. Kebanyakan melibatkan siswa dalam kelompok yang terdiri dari 4 (empat) siswa yang mempunyai kemampuan yang berbeda (Slavin, 1994), dan ada yang menggunakan ukuran kelompok yang berbeda-beda (Cohen, 1986; Johnson \&Johnson, 1994; Kagan, 1992; Sharan \& Sharan, 1992).

Menurut Johnson \& Johnson, dan Sharan, komponen-komponen penting dari pembelajaran kooperatif adalah sebagai berikut: (1) Ketergantungan positif; (2) Interaksi promotif langsung; (3) Akuntabilitas individual dan kelompok; (4) Keterampilanketerampilan antarpribadi dan kelompok kecil; (5) Pemrosesan kelompok

Selanjutnya menurut Slavin (2005, p.5) cooperative learning atau pembelajaran kooperatif dapat diaplikasikan untuk semua jenis kelas. Misalnya kelas khusus untuk anak-anak berbakat, kelas pendidikan khusus, kelas dengan kecerdasan rata-rata dan sangat di perlukan dalam kelas heterogen dengan berbagai tingkat kemampuan. Dalam penerapan metode cooperative learning terdapat konsep penting yang harus diterapkan. Tiga konsep penting yang menjadi sentral metode cooperative learning menurut Slavin (2005, p.10) adalah:

Pertama, Penghargaan kelompok (Team rewards), yang berarti suatu tim akan memperoleh penghargaan jika tim tersebut memenuhi kriteria yang ditentukan.

Kedua, Tangung jawab individu (Individual accountability), yang berarti kesuksesan tim tergantung pada belajar secara individu dari masing-masing anggota tim. Untuk memastikan bahwa setiap anggota kelompok memahami masalah yang dipelajari, dan mampu menyelesaikan kuis/ulangan secara mandiri, maka anggota tim harus saling membantu dalam menguasai masalah yang dipelajari.

Ketiga, Kesempatan sukses yang sama (Equal opportunities for success), yang berarti setiap anggota tim memiliki kesempatan yang sama untuk memberi kontribusi bagi kesuksesan tim dengan perkembangan masingmasing anggota dalam pencapaian hasil belajar.

Selain ketiga konsep diatas juga terdapat enam langkah utama atau tahapan dalam pembelajaran kooperatif. Pembelajaran dimulai dengan guru menyampaikan tujuan pelajaran dan memotivasi siswa untuk belajar. Tahap ini diikuti oleh penyajian informasi, yang bisa didapatkan dari berbagai sumber dan dijelaskan secara verbal. Selanjutnya siswa dikelompokkan ke dalam tim-tim belajar. Tahap ini diikuti bimbingan guru pada saat siswa bekerja bersama untuk menyelesaikan tugas bersama mereka. Tahap terakhir dari pembelajaran kooperatif adalah presentasi hasil akhir kerja kelompok atau evaluasi tentang apa yang telah dipelajari dan memberi penghargaan terhadap usaha-usaha kelompok maupun individu.

Jurusan otomotif merupakan suatu bidang cukup menarik untuk dikaji. Di dalamnya ternyata mempelajari berbagai ilmu yang dirangkum dalam sebuah ilmu otomotif. Sebagai contoh, ilmu kimia, matematika, fisika, termodinamika dan lain sebagainya. Berbagai ilmu ini dipadukan dan membentuk ilmu yang dapat diterapkan untuk kemajuan di bidang otomotif sampai sekarang.

Pembelajaran yang baik menempatkan siswa sebagai student centered. Siswa diharapkan dapat mengembangkan potensi dirinya melalui pembelajaran yang dilakukan oleh guru. Metode pembelajaran yang dilakukan guru dapat mengembangkan pengetahuan baru dan pengalaman yang sudah dimiliki siswa. Pembelajaran ini sering dinamakan PAIKEM (Pembelajaran, Aktif, Inovatif, Kreatif, Efektif dan Menyenangkan).

Pembelajaran aktif menumbuhkan siswa untuk menjadikan suasana belajar yang hidup ditandai dengan siswa yang berani mengemukakan pendapat, gagasan, dan ideide yang dimiliki ketika belajar di kelas. Pembelajaran inovatif memberikan kesempatan bagi siswa untuk berinovasi mengembangkan ide dalam pembelajaran dan bisa menemukan sesuatu melalui aktivitas belajarnya. Pembelajaran kreatif harus menumbuhkan pemikiran kritis dan kemampuan berfikir tentang sesuatu dengan cara baru serta 
dapat menghasilkan solusi unik atas suatu masalah yang dipelajari. Pembelajaran efektif merujuk pada berhasil guna untuk mencapai tujuan pembelajaran. Pembelajaran efektif mencakup tujuan pembelajaran dengan ranah afektif, kognitif dan psikomotorik. Sedangkan pembelajaran menyenangkan berarti suasana pembelajaran yang enak dirasakan oleh siswa. Siswa merasa tidak tertekan dengan pembelajaran ditandai dengan penuh keiklasan dalam belajar. Jika pembelajaran sudah sesuai seperti Pembelajaran Aktif, Inovatif, Kreatif, Efektif dan Menyenangkan ini sudah bisa dikatakan bahwa pembelajaran di kelas akan menjadi lebih menarik.

Berdasarkan survei yang dilakukan di SMK Ma'arif 1 Nanggulan Kulon Progo dapat digambarkan hal-hal sebagai berikut: (1) pengajaran materi produktif otomotif masih bersifat konvensional, terlihat dominasi guru yang sangat kuat dan terabaikannya kesempatan siswa untuk terlibat aktif dalam pembelajaran; (2) pembelajaran masih bersifat text books oriented, dimana siswa hanya dihadapkan pada tugas yang ada di buku teks dan modul yang dikerjakan secara individual; (3) lemahnya kontrol guru terhadap hasil kerja siswa, terbukti dengan kurangnya umpan balik terkait dengan pelajaran siswa baik pekerjaan rumah ataupun tugas yang diberikan guru dikelas, sehingga pemahaman siswa terhadap materi kurang; (4) kurang bervariasinya aktivitas yang diciptakan guru dalam pembelajaran yang menyebabkan siswa cepat bosan; dan (5) kurangnya keterampilan guru dalam mengelola dan mengorganisir kelas, dilihat dari bentuk kegiatan belajar yang lebih banyak individual, padahal jika dikelola bisa dibentuk kelompokkelompok.

Prestasi belajar kompetensi produktif otomotif kelas XI menunjukan nilai yang cukup rendah. Dari data bagian kurikulum di SMK Ma'arif 1 Nanggulan semester genap 2012/2013 menunjukan bahwa: (1) overhoul sistem pendingin dan komponenkomponennya nilai rata-rata teori 52,85 , nilai rata-rata praktik 73,19 sehingga rata-rata teori dan praktik 63,02; (2) Memelihara unit final drive/garden, nilai rata-rata teori 49.17 , nilai rata-rata praktik 75,60 sehingga rata-rata teori dan praktik 62,39; (3) Memperbaiki Rem nilai rata-rata teori 43,20, nilai rata-rata praktik 81,89 sehingga rata-rata teori dan praktik 62,55; dan (4) Memperbaiki Kerusakan Ringan Pada Rangkaian Kelistrikan, Pengaman dan Kelengkapan Tambahan, nilai rata-rata teori 56,82 , nilai rata-rata praktik 76,40 sehingga rata-rata teori dan praktik 66,61. Dari data diatas dapat disimpulkan bahwa beberapa nilai kompetensi produktif untuk semester genap pada tahun pembelajaran 2012/2013 masih rendah dan ada beberapa siswa yang masih di bawah Kriteria Ketuntasan Minimal (KKM) yaitu 70,00 . Hal ini mengindikasikan adanya ketidakpuasan siswa dalam mempelajari materi otomotif, sehingga output nilainya pun tidak sesuai dengan yang diharapkan. Kondisi tersebut juga menunjukkan bahwa ketidakpuasan lebih mendominasi dibandingkan dengan kepuasan.

Nilai rata-rata prestasi belajar teori dan praktek otomotif masih rendah. Padahal nilai Kriteria Ketuntasan Minimal (KKM) untuk mata pelajaran produktif otomotif minimal 70,00. Untuk menaikkan nilai tersebut menjadi (KKM) Kriteria Ketuntasan Minimal dengan dilakukan ujian ulang sehingga nilai yang ada di raport menjadi lebih tinggi. Program ujian ulang tentunya menambah waktu tambahan dalam pembelajaran karena dalam remedial berarti memberikan materi dan ujian ulang kepada siswa yang nilainya kurang. Selain itu, tidak sedikit guru yang belum memahami arti remedial, sehingga tidak sedikit pula guru yang hanya melakukan ujian ulang tanpa memberi materi.

Selama ini pemerintah telah memprogramkan pembelajaran tuntas (mastery learning). Jika dikaitkan dengan pembelajaran tuntas nilai siswa di SMK Ma'arif 1 Nanggulan masih jauh dari harapan. Belajar tuntas adalah suatu sistem belajar yang mengharapkan sebagian besar sasaran dapat menguasai tujuan instruksional umum (basic learning objective) dari satuan atau unit pelajaran secara tuntas. Untuk dianggap tuntas ditetapkan $85 \%$ dari populasi siswa harus menguasai sekurangkurangnya $75 \%$ dari tujuan instruksional yang dicapai. Dalam pelajaran produktif Di SMK Ma'arif 1 Nanggulan, di katakan pembelajaran 
tuntas jika minimal $85 \%$ dari siswa sudah sesuai dengan KKM dengan nilai minimal 70,00 .

Hal ini menunjukan bahwa pembelajaran di SMK Ma'arif 1 Nanggulan ada hal yang kurang dan perlu diperbaiki. Ada banyak hal yang dapat dilakukan oleh seorang guru, Salah satu caranya adalah dengan mengubah paradigma konvensional dan mengganti dengan menggunakan metode belajar inovatif dan produktif bagi siswa. Disamping untuk meningkatkan kualitas proses pembelajaran di kelas, pemilihan metode yang tepat akan memberikan ruang bagi siswa untuk lebih mampu mengembangkan kreasinya dalam menyelesaikan tugas-tugasnya.

Di SMK Ma'arif 1 Nanggulan, dalam wawancara yang dilakukan terhadap Wakil Kepala Sekolah bidang Kurikulum dan Kepala Sekolah menyatakan bahwa metode pembelajaran yang diterapkan oleh para guru monoton dan kurang memberi motivasi siswa dalam belajar. Konsep yang disarankan adalah metode Pembelajaran yang Aktif, Inovatif, Kreatif, Efektif dan Menyenangkan (PAIKEM). Jika konsep ini diterapkan harapannya akan memberikan prestasi belajar lebih baik.

Salah satu metode pembelajaran yang mendekati konsep ini yakni metode pembelajaran kooperatif (cooperative learning). Metode cooperative learning menekankan pada diskusi atau kerjasama dimana saling bertukar gagasan dan ide dalam kelompok. Metode ini memberikan ruang dan kesempatan bagi siswa untuk mempelajari materi dan interaksi sehingga pembelajaran lebih bersifat student centered dan bukan teacher centered.

Metode pembelajaran kooperatif tipenya cukup banyak. Namun yang dirasa tepat bagi siswa SMK Ma'arif 1 Nanggulan menurut peneliti adalah Team Game Tournament (TGT) dan Numbered Head Together (NHT). Dalam metode pembelajaran kooperatif tipe TGT, siswa memainkan permainan dengan anggota-anggota tim lain untuk memperoleh tambahan point untuk skor tim mereka. Keunggulan dalam pembelajaran kooperatif tipe TGT menggunakan permainan yang dapat disesuaikan dengan topik apapun. Permainan ini biasanya lebih baik daripada permainan individu, memberikan kesempatan bagi siswa untuk membantu satu sama lain dan menghindari sebuah masalah individu. Jika semua siswa menggabungkan kemampuanya dalam tim, semua siswa memiliki peluang yang baik untuk sukses. Dengan adanya games dan turnamen memungkinkan siswa dapat belajar lebih rileks disamping itu dapat menumbuhkan tanggung jawab, kejujuran, kerjasama, persaingan sehat, dan keterlibatan siswa dalam belajar. Borich, (2007, p.328), menjelaskan :

A Cooperative learning activity closely related to STAD in the use of teams games tournaments (TGT). TGT uses the some general format as STAD (four to five member groups studying work sheets). However, instead of individually administered quizzer at the and of a study period, students play academic games to show their mastery of the topic studies.

Suatu kegiatan pembelajaran kooperatif berhubungan erat dengan STAD yang digunakan oleh Team Game Tournament (TGT). TGT menggunakan format umum sama seperti STAD (4 samapi 5 anggota kelompok belajar setiap lembar kerja). Namun dari pada diberikan kuis individu dalam satu periode pembahasan, murid memainkan peranan akademis untuk memperlihatkan penguasaaan dari topik yang mereka pelajari. Slavin (2006, p.338), menjelaskan bahwa:

Teams-Games-Tournament, or TGT, uses games that can be adapted to any subject games are usually better than individual games, they provide an opportunity for teammates to help one another and avoid one problem of individual game which is that more able student might consistently win. If all students are put an mixed ability teams, all have a good chance of success.

Teams-Games-Tournament (TGT) menggunakan permainan yang dapat disesuaikan dengan topik apapun. Permainan ini biasanya lebih baik dari pada permainan individu, mereka memberikan kesempatan bagi rekan untuk membantu satu sama lain dan menghindari sebuah masalah permainan individu. Jika semua siswa menggabungkan kemampuanya 
dalam tim, semua siswa memiliki peluang yang baik untuk sukses.

Komponen TGT Slavin, (2005, p.166), adalah sebagai berikut :

\section{Presentasi kelas}

Materi dalam TGT pertama-tama diperkenalkan dalam presentasi di dalam kelas. Ini merupakan pengajaran langsung seperti yang sering kali dilakukan dalam kelas atau diskusi pelajaran yang dipimpin oleh guru, tetapi bisa juga memasukan presentasia udiovisual. Bedanya presentasi kelasdengan pengajaran biasa hanyalah bahwa presentasi tersebut haruslah bener-bener berfokus pada unit TGT. Dengan cara ini , para siswa akan menyadari bahwa mereka harus benar-benar memberi perhatian penuh selamapresentasi kelas, karena dengan demikian akan sangat membantu mereka mengerjakan kuis-kuis, dan skor kuis mereka menentukan tim mereka.

\section{Tim}

Tim terdiri dari empat atau lima siswa yang mewakili seluruh bagian dari kelas dalam hal kinerja akademik, jenis kelamin, ras, dan etnisitas. Fungsi utama dari tim ini adalah memastikan bahwa semua tim benarbenar belajar, dan lebih khususnya lagi adalah untuk mempersiapkan anggotanya untuk mempersiapkan kuis dengan baik. Setelah guru menyampaikan materinya, tim berkumpul untuk mempelajari lembar kegiatan atau materi lainya. Yang paling sering terjadi, pembelajaran itu melibatkan pembahasan permasalahan bersama, membandingkan jawaban dan mengkoreksi tiap kesalahan pemahaman apabila anggota tim ada yang membuat kesalahan.

\section{Turnamen}

Turnamen adalah sebuah struktur dimana game berlangsung. Biasanya berakhir pada akhir minggu atau akhir unit, setelah guru memberikan presentasi di kelas dan tim telah melaksanakan kerja kelompok terhadap lembar kegiatan. Pada turnamen pertama, guru menunjuk siswa berada pada meja turnamen. Tiga siswa berprestasi tertinggi sebelumnya berada pada meja 1 , tiga berikutnya pada meja 1 , dan seterusnya.

\section{Skor kemajuan individual}

Gagasan dibalik skor kemajuan individual adalah untuk memberikan kepada tiap siswa tujuan kinerja yang akan dapat dicapai apabila mereka bekerja lebih giat dan memberikan kinerja yang lenih abik dari pada sebelumnya.

\section{Rekognisi tim}

Tim akan mendapatkan sertifikat atau bentuk penghargaan yang lain apabila skor rata-rata mereka mencapai kriteria tertentu. Skor tim siswa dapat juga digunakan untuk menentukan dua puluh persen dari peringkat mereka.

Dalam metode Team Game Tournament (TGT), siswa memainkan permainan dengan anggota-anggota tim lain untuk memperoleh point tambahan untuk skor tim mereka. Pada tahap rekognisi tim, skor tim dihitung berdasarkan poin-poin turnamen yang diperoleh siswa pada setiap tim.

Menurut Huda (2013, p.130) metode pembelajaran kooperatif tipe NHT pada dasarnya merupakan varian dari diskusi kelompok. Teknik pelaksaananya hampir sama dengan diskusi kelompok. Diskusi kelompok dengan ciri khasnya adalah guru memberi nomor pada setiap anggota kelompoknya. Kemudian guru hanya menunjuk seorang siswa dengan menyebut salah satu nomor dalam kelompok mewakili kelompok tersebut. Sehingga cara ini menjamin keterlibatan total semua siswa dan upaya yang sangat baik untuk meningkatkan tanggung jawab individual dalam diskusi kelompok. Dalam menentukan keberhasilan kelompok tergantung pada keberhasilan individu, sehingga setiap anggota kelompok tidak bisa menggantungkan pada anggota yang lain. Dengan kata lain setiap individu mendapatkan kesempatan yang sama untuk menunjang timnya agar mendapat nilai yang maksimal. Oleh karena itu setiap siswa dituntut aktif dan kreatif dalam belajar. Setiap individu akan merasa mendapat tugas dan tanggung jawab diri sendiri, sehingga tujuan pembelajaran kooperatif dapat berjalan, bermakna dan tujuan pembelajaran dapat tercapai secara optimal sesuai dengan harapan kurikulum. 
Numbered Head Together (NHT) dikembangkan oleh Spencer Kagan dengan melibatkan para siswa dalam mereview bahan yang tercakup dalam suatu pelajaran dan mengecek atau memeriksa pemahaman mereka mengenai isi pelajaran tersebut. Penerapan pembelajaran kooperatif tipe NHT melibatkan lebih banyak siswa dalam menelaah materi yang tercakup dalam suatu pelajaran dengan mengecek pemahaman mereka mengenai isi pelajaran tersebut. Teknik ini bisa digunakan dalam semua mata pelajaran dan unutk tingkatan semua anak.

Pelaksanaan pembelajaran dengan menggunakan tipe NHT dilakukan dengan empat tahapan Lie (2008, p.60), Huda (2013, p.138) yaitu:

\section{Penomoran (Numbering)}

Siswa dikelompokan menjadi kelompokkelompok kecil yang terdiri dari 4 sampai 5 orang siswa. Setiap anggota kelompok memiliki kemampuan akademik serta jenis kelamin yang heterogen (satu berkemampuan tinggi, dua sedang, dan satu atau dua rendah). Selanjutnya, setiap anggota kelompok diberi nomor 1, 2, 3, 4, dan 5. Nomor yang dimiliki oleh setiap angggota kelompok akan mempermudah guru untuk menunjuk salah satu siswa dari setiap kelompok untuk mengerjakan tugas, memberikan pertanyaan dan sebagainya.

\section{Pengajuan Pertanyaan}

Guru mengajukan pertanyaan dan memberikan tugas, kemudian masing-masing kelompok mengerjakanya.

\section{Berpikir Bersama}

Kelompok memutuskan jawaban yang dianggap paling benar dan memastikan setiap anggota kelompok mengetahuai jawaban yang telah disepakati oleh semua anggota kelompok.

\section{Pemberian Jawaban}

Guru memanggil salah satu nomor secara acak. Semua siswa yang memiliki nomor yang disebutkan oleh guru harus bersiap untuk presentasi, karena guru akan memilih satu kelompok secara acak. Siswa dengan nomor dan kelompok yang dipanggil mempresentasikan hasil kerjasama mereka.
Pembelajaran kooperatif tipe TGT dan tipe NHT untuk memotivasi siswa supaya dapat saling mendukung dan saling membantu satu sama lain dalam pembelajaran kooperatif tipe TGT dan tipe NHT sesuai untuk pembelajaran otomotif. Informasi-informasi serta materi otomotif yang berupa pengertian, nama komponen, prinsip kerja, langkah kerja, prosedur pemasangan dan pembongkaran akan lebih baik apabila didiskusikan dengan beberapa siswa. Materi yang disajikan dari yang bersifat umum menuju yang khusus, akan memancing siswa agar siswa berpikir secara deduktif. Materi yang tidak terlalu banyak uraian dalam menyelesaikan juga sesuai untuk menjadi soal evaluasi yang berbentuk kuis maupun games. Dari permasalahan yang telah diuraikan diatas maka penelitian ini dilakukan untuk mengetahui pengaruh metode pembelajaran kooperatif tipe TGT dan tipe NHT terhadap prestasi belajar dan kepuasan pembelajaran kelistrikan otomotif siswa kelas XI SMK Ma'arif 1 Nanggulan Kulon Progo.

\section{METODE PENELITIAN}

\section{Jenis penelitian}

Penelitian ini merupakan penelitian quasi eksperimen atau eksperimen semu. Variabel terikat dalam penelitian ini yaitu prestasi belajar dan kepuasan pembelajaran kelistrikan otomotif dengan variabel bebas metode pembelajaran koopertif tipe TGT dan NHT. Desain penelitian yang digunakan adalah Quasi-Experiments dengan Nonequivalent (pretest and post-test) group design.

\section{Waktu dan tempat penelitian}

Penelitian ini dilakukan di SMK Ma'arif 1 Nanggulan Kulon progo pada bulan Juli sampai bulan September 2013. Penelitian ini dilakukan dikelas XI pada semester gasal tahun ajaran $2013 / 2014$. Kompetensi yang diambil pada penelitian ini adalah motor starter otomotif

\section{Teknik pengumpulan data}

Dalam penelitian ini, data diperoleh langsung dengan memberikan perlakuan kepada kedua kelas eksperimen. Dengan demikian, data penelitian merupakan data 
Tabel 1. Data tes prestasi belajar motor starter

\begin{tabular}{lcccc}
\hline \multirow{2}{*}{ Deskripsi } & \multicolumn{2}{c}{ Kelompok TGT } & \multicolumn{2}{c}{ Kelompok NHT } \\
\cline { 2 - 5 } & Pre-Test & Post-test & Pre-test & Post-test \\
\hline Rata-rata & 41,25 & 80,45 & 37,5 & 75,08 \\
Nilai maksimum teoritik & 100 & 100 & 100 & 100 \\
Nilai minimum teoritik & 0 & 0 & 0 & 0 \\
Nilai maksimum & 63 & 93,5 & 63 & 86 \\
Nilai minimum & 23 & 66 & 20 & 53 \\
Standar Deviasi & 10 & 7,3 & 11,76 & 7,58 \\
Variasi & 100,06 & 53,29 & 138,41 & 57,49 \\
\hline
\end{tabular}

Tabel 2. Data kepuasan belajar siswa

\begin{tabular}{lcccc}
\hline \multirow{2}{*}{ Deskripsi } & \multicolumn{2}{c}{ Kelompok TGT } & \multicolumn{2}{c}{ Kelompok NHT } \\
\cline { 2 - 5 } & Pre-Test & Post-test & Pre-test & Post-test \\
\hline Rata-rata & 60,07 & 120,53 & 61,10 & 105,03 \\
Nilai maksimum teoritik & 140 & 140 & 140 & 140 \\
Nilai minimum teoritik & 28 & 28 & 28 & 28 \\
Nilai maksimum & 77 & 137 & 78 & 135 \\
Nilai minimum & 34 & 101 & 33 & 84 \\
Standar Deviasi & 11,09 & 10,30 & 11,29 & 12,38 \\
Variasi & 123,09 & 106,18 & 127,54 & 153,257 \\
\hline
\end{tabular}

primer. Teknik pengumpulan data dengan tes untuk mengukur prestasi belajar belajar motor starter dan non tes untuk mengukur kepuasan pembelajaran

\section{Teknik analisis data}

Data penelitian yang dianalisis adalah data kondisi awal dan akhir pada aspek kepuasan pembelajaran motor starter dan prestasi belajar motor starter. Data kondisi awal untuk mengetahui gambaran awal kedua kelompok siswa kemudian selanjutnya kondisi akhir untuk mendeskripsikan data perbedaan keefektifan metode pembelajaran kooperatif tipr TGT dan NHT

\section{HASIL PENELITIAN DAN \\ PEMBAHASAN}

\section{Deskripsi Data}

\section{Data tes prestasi belajar motor starter}

Berdasarkan kriteria ketuntasan prestasi belajar yang dapat dilihat pada tabel 1 , ratarata prestasi belajar kedua kelas eksperimen sudah memenuhi standar ketuntasan minimal (70) dan cukup jauh dari standar ketuntasan minimal

\section{Data kepuasan belajar siswa}

Berdasarkan rata-rata yang diperoleh menunjukan peningkatan kedua metode pembelajaran kooperatif tipe TGT dan NHT setelah dilaksanakan penelitian adalah meningkat karena rata-rata lebih dari 74,99 yang dapat dilihat pada tabel 2 .

\section{Analisis Data}

\section{Analisis efektivitas metode pembelajaran}

a. Analisis efektivitas masing-masing metode pembelajaran ditinjau dari aspek prestasi belajar motor starter.

Pertama, Dari hasil analisis menggunakan SPSS 15 for windows diperoleh $\mathrm{t}_{\text {hitung }} 60,35$ dengan nilai signifikansi 0,000 . Jika dikaitkan dengan kriteria pengujian dengan nilai signifikansi 0,05 maka $\mathrm{H}_{\mathrm{o}}$ ditolak. Jadi dapat disimpulkan bahwa metode pembelajaran kooperatif tipe TGT efektif terhadap prestasi belajar motor starter siswa. 
Tabel 3. Uji normalitas kondisi awal

\begin{tabular}{llcc}
\hline Kelompok & Variabel & Nilai Signifikasi & Kriteria \\
\hline TGT & Kepuasan pembelajaran & 0,200 & Normal \\
& Prestasi belajar & 0,200 & Normal \\
\multirow{2}{*}{ NHT } & Kepuasan pembelajaran & 0,188 & Normal \\
& Prestasi belajar & 0,200 & Normal \\
\hline
\end{tabular}

Tabel 4. Uji normalitas kondisi akhir

\begin{tabular}{llcc}
\hline Kelompok & Variabel & Nilai Signifikasi & Kriteria \\
\hline TGT & Kepuasan pembelajaran & 0,200 & Normal \\
& Prestasi belajar & 0,143 & Normal \\
\multirow{2}{*}{ NHT } & Kepuasan pembelajaran & 0,184 & Normal \\
& Prestasi belajar & 0,200 & Normal \\
\hline
\end{tabular}

Kedua, Dari hasil analisis menggunakan SPSS 15 for windows diperoleh $t_{\text {hitung }} 54,23$ dengan nilai signifikansi 0,000 . Jika dikaitkan dengan kriteria pengujian dengan nilai signifikansi 0,05 maka $\mathrm{H}_{\mathrm{o}}$ ditolak. Jadi dapat disimpulkan bahwa metode pembelajaran kooperatif tipe NHT efektif terhadap prestasi belajar motor starter siswa

2. Analisis efektivitas masing-masing metode pembelajaran ditinjau dari aspek kepuasan pembelajaran motor starter.

Pertama, dari hasil analisis menggunakan SPSS 15 for windows diperoleh $\mathrm{t}_{\text {hitung }} 64,066$ dengan nilai signifikansi 0,000 . Jika dikaitkan dengan kriteria pengujian dengan nilai signifikansi 0,05 maka $\mathrm{H}_{\mathrm{o}}$ ditolak. Jadi dapat disimpulkan bahwa metode pembelajaran kooperatif tipe TGT efektif terhadap kepuasan pembelajaran siswa.

Kedua, Dari hasil analisis menggunakan SPSS 15 for windows diperoleh $\mathrm{t}_{\text {hitung }} 46,468$ dengan nilai signifikansi 0,000 . Jika dikaitkan dengan kriteria pengujian dengan nilai signifikansi 0,05 maka $\mathrm{H}_{\mathrm{o}}$ ditolak. Jadi dapat disimpulkan bahwa metode pembelajaran kooperatif tipe NHT efektif terhadap kepuasan pembelajaran siswa

\section{Analisis kondisi awal}

\section{Uji Normalitas}

Karena nilai signifikansinya $>0,05$ maka prestasi belajar dan kepuasan pembelajaran pada kedua kelompok berdistribusi normal yang dapat dilihat pada tabel 3 .

\section{Uji Homogenitas matriks varians-kovarians}

Hasil perhitungan SPSS 15 for windows diperoleh signifikansi 0,591>0,05 maka disimpulkan bahwa matriks varians-kovarians kedua populasi adalah sama atau homogen.

\section{Uji homogenitas varian}

Hasil pengujian terhadap masing-masing variabel dengan menggunakan SPSS 15 for windows, menunjukan nilai signifikansi pada aspek prestasi belajar motor starter adalah 0,220 dan pada aspek kepuasan pembelajaran siswa adalah 0,822 , karena nilai signifikansi masing-masing variabel lebih besar dari taraf signifikansi 0,05 maka disimpulkan varians kedua populasi sama atau homogen, yang berkenaan dengan variabel dependent prestasi belajar dan kepuasan pembelajaran motor stater siswa.

\section{Uji multivariat}

Hasil perhitungan dengan SPSS 15 for windows menunjukan bahwa angka signifikansi 0,410. Jika dikaitkan dengan kriteria penerimaan, angka signifikansi $>0,05$ maka $\mathrm{H}_{\mathrm{O}}$ diterima. Karena itu disimpulkan bahwa prestasi belajar dan kepuasan pembelajaran siswa pada motor starter siswa di kelas TGT tidak berbeda dengan prestasi belajar dan kepuasan pembelajaran siswa di kelas NHT, atau dengan kata lain kondisi awal subjek penelitian pada kedua kelompok sama ditinjau dari prestasi belajar dan kepuasan pembelajaran siswa pada motor starter. 


\section{Analisis kondisi akhir}

\section{Uji Normalitas}

Karena nilai signifikansinya $>0,05$ maka prestasi belajar dan kepuasan pembelajaran pada kedua kelompok berdistribusi normal yang dapat ilihat pada tabel 4 .

\section{Uji Homogenitas matriks varians-kovarians}

Pengujian homogenitas untuk uji multivariat menggunakan uji Box's $M$ test. Hasil perhitungan SPSS 15 for windows diperoleh signifikansi $0,092>0,05$ maka disimpulkan bahwa matriks varians-kovarians kedua populasi adalah sama atau homogeny

\section{Uji homogenitas varian}

Pengujian terhadap masing-masing variabel dengan menggunakan SPSS 15 for windows, menunjukan nilai signifikansi pada aspek prestasi belajar motor starter adalah 0,822 dan pada aspek kepuasan pembelajaran siswa adalah 0,493 , karena nilai signifikansi masing-masing variabel lebih besar dari taraf signifikansi 0,05 maka dapat disimpulkan varians kedua populasi sama atau homogen, yang berkenaan dengan variabel dependent prestasi belajar dan kepuasan pembelajaran siswa pada motor stater.

\section{Uji hipotesis}

\section{Uji Multivariat}

Pengujian hipotesis tahap pertama

Berdasarkan hasil pengujian dengan menggunakan program SPSS 15 for windows diperoleh nilai $\mathrm{F}=15,936$ atau nilai signifikansi 0,000. Jika dikaitkan dengan taraf signifikansi $5 \%$ maka $\mathrm{H}_{0}$ ditolak. Sehingga dapat disimpulkan bahwa terdapat perbedaan keefektifan metode pembelajaran kooperatif tipe TGT dan tipe NHT ditinjau dari prestasi belajar dan kepuasan pembelajaran siswa.

\section{Uji Unvariat}

Pengujian hipotesis tahap kedua

Hasil uji hipotesis menggunakan bantuan SPSS 15 for windows menunjukan nilai $\mathrm{t}=$ 2,793 atau nilai signifikansi adalah 0,007 . Jika dikaitkan dengan nilai signifikansi 0,025 maka $\mathrm{H}_{\mathrm{o}}$ ditolak. Sehingga dapat disimpulkan bahwa metode pembelajaran kooperatif tipe TGT lebih efektif dibanding metode pembelajaran kooperatif tipe NHT terhadap prestasi belajar motor starter siswa.

\section{Pengujian hipotesis tahap kedua}

Hasil uji hipotesis menggunakan bantuan SPSS 15 for windows menunjukan nilai $t=$ 5,271 atau nilai signifikansi adalah 0,000 . Jika dikaitkan dengan nilai signifikansi 0,025 maka $\mathrm{H}_{0}$ ditolak. Sehingga dapat disimpulkan bahwa metode pembelajaran kooperatif tipe TGT lebih efektif dibanding metode pembelajaran kooperatif tipe NHT terhadap kepuasan pembelajaran motor starter siswa

\section{PEMBAHASAN HASIL PENELITIAN}

Instrumen penelitian yang digunakan adalah instrumen prestasi belajar motor starter dan instrumen kepuasan pembelajaran siswa. Kedua instrumen tersebut divalidasi oleh dua orang dosen. Satu orang dosen memiliki gelar akademik profesor dan satu orang dosen lagi memiliki gelar akademik doktor. Dari hasil validasi para ahli tersebut berpendapat bahwa instrumen layak digunakan jika direvisi. Intrumen direvisi kemudian dilakukan ujicoba di lapangan pada siswa kelas XII SMK Ma'arif 1 Nanggulan Kulon Progo sejumlah 30 orang siswa untuk melihat kevalidan dan reliabel.

Hasil uji validitas dan reliabilitas menunjukan 39 item instrumen prestasi belajar motor starter dinyatakan valid dan reliabel. Sedangkan 28 item instrumen kepuasan pembelajaran pada motor starter menunjukan valid dan reliabel. Setelah dilakukan uji validitas dan reliabilitas menyatakan valid dan reliabel atau dengan kata lain instrumen tersebut layak digunakan untuk penelitian.

Saat penelitian berlangsung, metode pembelajaran kooperatif tipe TGT dan NHT dijadikan sebagai alternatif metode pembelajaran yang digunakan. Sebelum kedua kelas diberikan eksperimen ditinjau dari aspek prestasi belajar dan kepuasan pembelajaran siswa. Terlebih dahulu dilihat kondisi awal kedua kelas eksperimen. Data awal dilakukan uji normalitas untuk menguji apakah data berdistribusi normal dan uji homogenitas untuk menguji matriks varians-kovarians 
menunjukan bahwa data berdistribusi normal dan homogen. Setelah memenuhi kriteria normal dan homogen yang menyatakan data berdistribusi normal dan homogen dilanjutkan dengan uji hipotesis multivariat, untuk melihat kondisi awal kedua kelompok ditinjau dari prestasi belajar motor starter dan kepuasan pembelajaran siswa yang menunjukan kedua kelompok sama.

Berdasarkan hasil eksperimen kedua metode pembelajaran kooperatif menunjukan bahwa terdapat perbedaan metode pembelajaran kooperatif tipe TGT dengan metode pembelajaran kooperatif tipe NHT di tinjau dari aspek prestasi belajar dan kepuasan pembelajaran siswa dengan menggunakan uji Hotelling Trace $\left(T^{2}\right)$. Hal ini memungkinkan untuk melanjutkan pengujian dengan uji $t$ dan hasilnya menunjukan bahwa pembelajaran motor starter dengan metode pembelajaran kooperatif tipe TGT lebih efektif dari metode pembelajaran kooperatif tipe NHT ditinjau dari aspek prestasi belajar dan kepuasan pembelajaran siswa. Hasil-hasil analisis tersebut akan dibahas satu persatu sebagai berikut:

\section{Keefektifan Metode Pembelajaran}

Pelaksanaan penelitian dengan metode pembelajaran kooperatif tipe TGT diawali dengan membagi kelompok sejumlah 6 kelompok. Kelompok-kelompok tersebut mengerjakan LKS, kemudian perwakilan kelompok untuk mempresentasikan di depan kelas hasil diskusi kelompoknya. Setelah siswa telah melaksanakan diskusi kelompok maupun diskusi kelas maka siswa diberikan permainan yang terbagi dalam meja-meja turnamen. Hal inilah yang menyebabkan metode pembelajaran kooperatif tipe TGT efektif terhadap prestasi belajar dan kepuasan pembelajaran siswa.

Metode pembelajarn kooperatif tipe NHT diawali dengan membagi kelompok sejumlah 5 kelompok. Masing-masing anggota kelompok diberi nomor sesuai dengan jumlah anggotanya. Nomor yang dimiliki oleh setiap angggota kelompok akan mempermudah guru untuk menunjuk salah satu siswa dari setiap kelompok untuk mengerjakan tugas, memberikan pertanyaan dan sebagainya. Guru mengajukan pertanyaan kepada kelompok dan memberikan tugas, kemudian masingmasing kelompok mengerjakanya. Kelompok memutuskan jawaban yang dianggap paling benar dan memastikan setiap anggota kelompok mengetahuai jawaban yang telah disepakati oleh semua anggota kelompok. Guru memanggil salah satu nomor secara acak. Semua siswa yang memiliki nomor yang disebutkan oleh guru harus bersiap untuk presentasi, karena guru akan memilih satu kelompok secara acak. Siswa dengan nomor dan kelompok yang dipanggil mempresentasikan hasil kerjasama mereka. Hal inilah yang menyebabkan metode pembelajaran kooperatif tipe NHT efektif terhadap prestasi belajar dan kepuasan pembelajaran siswa.

Fakta ini didukung oleh keefektifan aspek prestasi belajar motor starter dan kepuasan pembelajaran siswa kelas XI Oto1 yang diajarkan dengan metode pembelajaran kooperatif tipe TGT dan siswa kelas XI Oto 3 yang diajarkan dengan metode pembelajaran kooperatif tipe NHT. Jika dikaitkan dengan kriteria ketuntasan minimal yang telah ditetapkan dan hasil uji one sample $t$ test maka dapat disimpulkan bahwa baik metode pemebelajaran kooperatif tipe TGT dan metode pembelajaran kooperatif tipe NHT efektif dalam pencapaian tujuan pembelajaran motor starter otomotif di tinjau dari aspek prestasi belajar siswa dan kepuasan pembelajaran siswa motor starter otomotif.

Sejalan dengan hasil penelitian slavin (2005:60) yang menyatakan bahwa penelitian terhadap pembelajaran kooperatif dan hubunganya dengan para siswa yang cacat akademik dengan siswa yang perkembanganya normal secara umum menunjukan bahwa pembelajaran kooperatif dapat mengatasi hambatan terhadap pertemanan dan interaksi diantara para siswa mengusahakan pencapaian bagi semua siswa ini. Lebih jauh lagi, perkembangan ini dapat diperoleh para siswa mengusahakan pencapaian bagi semua siswa di dalam kelas.

\section{Perbedaan Keefektifan Metode Pembelajaran}

Hasil uji Hotelling Trace $\left(T^{2}\right)$ menunjukan bahwa terdapat perbedaan keefektifan 
metode pembelajaran kooperatif tipe TGT dengan metode pembelajaran kooperatif tipe NHT ditinjau dari aspek prestasi belajar dan kepuasan pembelajaran siswa. Perbedaan yang dibuktikan dengan uji hipotesis ini menunjukan bahwa meskipun kedua metode pembelajaran terdapat perbedaan keefektifan tetapi memiliki keunggulan dan kelemahan masing-masing.

Hasil uji $t$ menunjukan bahwa pembelajaran motor sarter dengan metode pembelajaran kooperatif tipe TGT lebih efektif dibanding pembelajaran motor starter dengan metode pembelajaran kooperatif tipe NHT ditinjau dari aspek prestasi belajar dan kepuasan pembelajaran siswa. Hal ini disebabkan metode pembelajaran kooperatif tipe TGT yang menekankan peran siswa untuk belajar secara kelompok dan masing-masing siswa bertanggung jawab atas kesuksesan individu maupun kelompok, mendorong siswa untuk saling membantu memahami materi pelajaran karena kesuksesan masing-masing individu juga ditentukan oleh individu yang lain dalam kelompok yang sama.

Metode pembelajaran kooperatif tipe TGT efektif untuk kepuasan pembelajaran siswa dalam belajar motor starter baik dikelas maupun secara individu dirumah. Kepuasan pembelajaran siswa yang tinggi tentunya menjadi faktor yang sangat berperan dalam menentukan kesuksesan siswa dalam belajar motor starter. Pada metode pembelajaran kooparatif tipe TGT Kepuasan pembelajaran siswa dibangun ketika memperoleh penghargaan baik dari guru maupun dari teman ketika belajar kelompok. Siswa yang dipuji, dihargai ketika mengemukakan pendapat akan semakin tekun untuk belajar dan menyelesaikan tugastugas akademik yang baik, dan pada akhirnya dapat mencapai prestasi belajar yang baik.

\section{SIMPULAN DAN SARAN}

\section{Simpulan}

Metode pembelajaran kooperatif tipe TGT dan metode pembelajaran kooperatif tipe NHT efektif terhadap prestasi belajar dan kepuasan pembelajaran motor starter siswa kelas XI SMK Ma'arif 1 Nanggulan Kulon Progo tahun pelajaran 2012/2013.
Metode pembelajaran kooperatif tipe TGT lebih efektif dibanding metode pembelajaran kooperatif tipe NHT terhadap prestasi belajar dan kepuasan pembelajaran motor starter siswa kelas XI SMK Ma'arif 1 Nanggulan Kulon Progo tahun pelajaran 2012/2013.

\section{Saran}

Berdasarkan hasil serta temuan penelitian, dan dengan memperhatikan keterbatasan penelitian, saran yang dapat disampaikan adalah sebagai berikut:

Pertama, Metode pembelajaran kooperatif tipe TGT dan metode pembelajaran kooperatif tipe NHT efektif karena itu disarankan agar menerapkanya dalam pembelajaran motor starter.

Kedua, Metode pembelajaran kooperatif tipe TGT lebih efektif dibanding metode pembelajaran kooperatif tipe NHT karena itu disarankan agar para guru hendaknya menerapkan metode pembelajaran kooperatif tipe TGT untuk mencapai hasil yang optimal.

Disarankan untuk menerapkan metode pembelajaran kooperatif tipe TGT dan NHT pada materi pokok yang lain dan variabel dependen yang lain.

\section{DAFTAR PUSTAKA}

Borich, G. D. (2000). Effective teaching methods. New Jearsey: Mac millan Publishing Company.

Creswell, J. W. (2009). Research design. Qualitative, quantitative, and mixed Methods Approaches.London: SAGE Publications.Inc

Depdiknas. (2003). Undang-undang RI Nomor 20, Tahun 2003, tentang Sistem Pendidikan Nasional. . (2005). Peraturan Pemerintah RI Nomor 19, Tahun 2005, tentang Standar Nasional Pendidikan.

(2007). Peraturan Menteri Pendidikan Nasional RI Nomor 41, Tahun 2007, tentang standar Proses 
Dittrich, J. et al. (2009). Standardisation in TVET teacher education. Alle Reche vorbehalten: Peter Lang GmbH.

Finch, C. R. \& Crunkilton, J. R. (1999). Curriculum development in vocational and technical education: planning, content, and implementation. Sidney: Allyn and Bacon Inc.

Huda, M. (2005). Cooperatiflearning. metode, teknik, struktur, dan model penerapan. Yogyakarta: Pustaka Pelajar.

Jacobs, G. (2010). Cooperative learning: theory, principles, and techniques. Diambil pada tanggal 5 April 2012, dari http://www. readingmatrix.com/ conference/pp/proceedings/jacobs.pdf

Johnson, D.W., \& Johnson, R. (1989). Cooperative and competion: Theoru and research. Edina,MN: Interaction Book Company.

Lie, A. (2008). Mempraktikan cooperatif learning di ruang-ruang kelas.Jakarta: Grasindo.

Sanjaya, W. (2007). Strategi pembelajaran berorientasi standar proses pendidikan. Jakarta: Kencana Prenada Media.
Sharan, Y., \& Shlomo, S. (1992). Expanding cooperative learning throuhg group investigation, New York: Teachers Collage Press.

Slavin, R. E.(2005). Cooperative learning: Teori, riset dan praktik. (Terjemahan Narulita Yusron). Boston: Allyn and Bacon. (Buku asli diterbitkan tahun 1995)

(2006). Educational psychology: theory, and practise. Boston: Allyn and Bacon.

Solihatin, E.,\& Raharjo.(2009). Cooperative learning: analisis model pembelajaran IPS. Yogyakarta: Bumi Aksara.

Suprijono, A. (2010). Cooperative learning, teori dan aplikasi PAIKEM. Yogyakarta: Pustaka Pelajar.

Sugihartono, dkk. (2007). Psikologi pendidikan. Yogyakarta: UNY Press.

Wachanga, S. W., \& Mwangi, J. G. (2004). Effects of the cooperative class experiment teaching method on secondary school students chemistry achievement in Kenya's Nakuru District. International Education Journal, 8, 26-35. 